Ks. Franciszek DRĄCZKOWSKI

(Lublin, KUL)

\title{
KONCEPCJA WYCHOWANIA CHRZEŚCIJAŃSKIEGO W UJĘCIU KLEMENSA ALEKSANDRYJSKIEGO ORAZ JANA CHRYZOSTOMA
}

$\mathrm{Na}$ wstępie warto przypomnieć, że Klemens Aleksandryjski i Jan Chryzostom należą do najwybitniejszych przedstawicieli dwóch wielkich ośrodków starożytnej myśli chrześcijańskiej: aleksandryjskiego i antiocheńskiego. Klemens, żyjący na przełomie II i III wieku, twórca teologii spekulatywnej, zaliczany jest do grona czołowych teoretyków pedagogiki chrześcijańskiej. Jan Chryzostom, żyjący na przełomie IV i V wieku, najwybitniejszy homileta Kościoła greckiego, gorliwy duszpasterz, moralista i asceta, aplikował teoretyczne zasady pedagogiki do potrzeb duszpasterskich i formacyjnych. Koncepcje wychowania chrześcijańskiego obu tych wielkich nauczycieli Kościoła, wyrosłe na bazie różnych szkół, stąd odmienne w swych ujęciach, zdradzają jednak więcej podobieństw niż różnic, jako że wyrosły ze wspólnego pnia nauki chrześcijańskiej oraz tradycji klasycznej.

Termin $\pi \alpha \imath \delta \alpha \gamma \omega \gamma^{\prime} \alpha$, tak kluczowy dla postawionej w powyższym temacie problematyki, został wprowadzony do literatury wczesnochrześcijańskiej przez Klemensa Aleksandryjskiego ${ }^{1}$, który plasuje całą problematykę wychowawczą w pięciu grupach szczegółowych. Jego zdaniem pedagogia traktuje o: 1. wychowankach, 2. wychowawcach, 3 . metodzie, 4. programie, 5. celu wychowania ${ }^{2}$. W ramach powyższego podziału zostanie omówiona problematyka niniejszego artykułu.

1. Wychowankowie. Klemens Aleksandryjski wychodząc od etymologii terminu $\pi \alpha i \delta \alpha \gamma \omega \gamma i \alpha$ ( $\pi \alpha \hat{\imath} \varsigma$ - dziecko; $\alpha \gamma \omega \gamma \eta \dot{~-~ p r o w a d z e n i e, ~ k i e r o w a n i e) ~}$ określa, że wychowankami „Bożej pedagogii” 3 są „,dzieci” w rozumieniu specyficznym, to jest takim, jaki występuje w Piśmie Ś Siętym. Przypomina, że

\footnotetext{
${ }^{1}$ Por. Clemens Alexandrinus, Paedagogus, I 12, 1; 16, 1; 54, 1; 74, 3; 99, 2.

${ }^{2}$ Por. tamże I 54, 1.

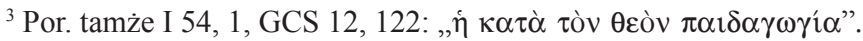


Chrystus nazywa swych uczniów, którzy byli ludźmi dorosłymi, „dziećmi”. Kontynuując swój wywód Klemens stwierdza:

„Należy jednak zastanowić się kim są dzieci, o których w sposób symboliczny mówi Pismo, i wyznaczyć dla nich pedagoga. Dziećmi tymi jesteśmy my"5.

Ostatnie słowa powyższej wypowiedzi wyraźnie określają, że w koncepcji Klemensa wychowankami „Boskiej pedagogii” są wszyscy wierzący w Chrystusa, niezależnie od kategorii wiekowej, to znaczy tak dzieci i młodzież, jak i dorośli oraz starsi wiekiem. Kategorię „dzieci” ( $\pi \alpha \hat{\imath} \delta \varepsilon \varsigma)$ odnosi Aleksandryjczyk do całego ludu Bożego, który jest na etapie ciągłego wzrostu i dojrzewania ku doskonałości. Mając na uwadze tę kategorię, Klemens odnosi do ludu Bożego szereg określeń synonimicznych, oznaczających status ciągłego rozwoju i wzrostu młodego potomstwa:

„Tak więc jesteśmy pisklętami Pana. Istotnie w sposób cudowny i mistyczny Logos nadaje wiekowi dziecięcemu prostotę ducha, Raz nazywa nas dziećmi, innym razem pisklętami, niekiedy niemowlętami, gdzie indziej zaś synami, a często dziećmi, ludem nowym lub ludem młodym"6.

Na bazie powyższych założeń cały Kościół - w nauce Klemensa - postrzegany jest jako „szkoła” Boskiego Logosu: „Szkołą jest Kościół” ( $\delta 1 \delta \alpha \sigma \kappa \alpha \lambda \varepsilon \hat{\imath} o v$ $\delta \grave{\varepsilon} \dot{\eta} \dot{\varepsilon} \kappa \kappa \lambda \eta \sigma i \alpha)^{7}$. Wychowankami - alumnami tej ,szkoły” są ci wszyscy, którzy przynależą do ludu Bożego. Z uwagi na stopień zaawansowania w procesie doskonalenia, alumni szkoły Logosu - zdaniem Klemensa - mogą być zaszeregowani do trzech grup. Do pierwszej grupy, najmniej zaawansowa-

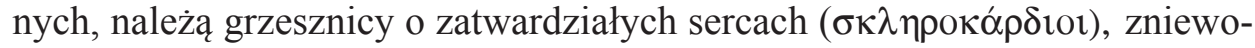
leni przez grzech, stąd określani też jako „niewolnicy” ( $\delta \circ \hat{\lambda} \lambda \circ \mathrm{)})$. Do drugiej

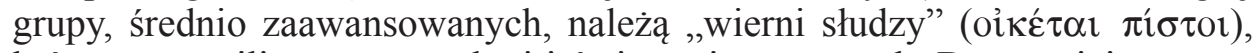
którzy porzucili grzeszne nałogi i ćwiczą się w cnotach. Do trzeciej grupy najbardziej zaawansowanych - należą przyjaciele Chrystusa ( $\varphi$ í $\lambda \circ$ ), którzy przez doskonałą miłość upodobnili się do Boga ${ }^{8}$.

Wszyscy, wyżej wymienieni, są wychowankami Szkoły Chrystusowej, którą jest Kościół, niezależnie od stopnia postępu na drodze doskonalenia, jak i statusu społeczno-rodzinnego oraz wiekowego: dzieci i rodzice, młodzieńcy i starcy, grzesznicy i święci, nawracający się oraz wierni słudzy, dążący do doskonałości oraz przyjaciele Boga.

${ }^{4}$ Por. tamże I 12, 2; 13, 3 (zob. J 21, 4-5; 13, 33).

${ }^{5}$ Tamże I 12, 1, GCS 12, 96, thum. T. Puton: Pedagog. Księga I Klemensa Aleksandryjskiego, wstęp, tłumaczenie, komentarz, Lublin 1977, Biblioteka KUL mps [181/77, Fil. klasycz.]. Wszystkie cytaty z I księgi Pedagoga dalej przytaczam w przekładzie T. Putona.

${ }^{6}$ Paedagogus I 14, 5, GCS 12, 98.

${ }^{7}$ Tamże III 98, 1, GCS 12, 289.

${ }^{8}$ Por. Clemens Alexandrinus, Stromata I 173, 6; VII 5, 6; zob. F. Drączkowski, Kościót-Agape wedtug Klemensa Aleksandryjskiego, Lublin 1996², 136-146 (Kościół jako Szkoła Logosu). 
Jan Chryzostom pisząc o wychowankach ma na uwadze określoną barierę wiekową, to jest, okres od wczesnego dzieciństwa do czasu narzeczeństwa i zaślubin. Wychowankami według niego są zarówno małe dzieci, chłopcy i dziewczęta do lat ośmiu, jak i młodzież w wieku dojrzewania do lat piętnastu oraz młodzież dojrzała do małżeństwa9. Trudno określić, jaką granicę wiekową miał na myśli Jan Chryzostom mówiąc o dojrzałości do małżeństwa. Ze względu na zachowanie czystości przedmałżeńskiej Biskup Konstantynopola postulował wczesne zawarcie związku małżeńskiego, przed służbą wojskową i objęciem posady państwowej ${ }^{10}$.

2. Wychowawcy. Według Klemensa Aleksandryjskiego wychowawcą najdoskonalszym i w istocie rzeczy jedynym jest odwieczne Słowo Ojca, Syn Boży, Boski Pedagog ${ }^{11}$. Zdaniem Klemensa Boski Logos jest wychowawcą wszystkich ludzi w wymiarze uniwersalnym, zarówno w aspekcie historycznym jak i geograficznym. W czasach Starego Przymierza ,przez Mojżesza Bóg sprawował funkcję wychowawcy, następnie przez proroków"12. Zdaniem Klemensa, Boski Logos przez filozofię, którą dał Hellenom ${ }^{13}$, stał się pośrednio ich wychowawcą. Mówiąc o filozofii Klemens ma na uwadze tylko tę, która jest „zgodna z Boskim Logosem”14. W ten sposób filozofia stała się dla Hellenów jakby trzecim Testamentem ${ }^{15}$. Boski Logos jest wychowawcą ludu Bożego:

„Naszym Pedagogiem jest święty Bóg, Jezus, kierownik całej ludzkiej natury,

Logos; sam Bóg, który kocha ludzi, jest naszym Pedagogiem"16.

Ze względu na wyżej omówione zróżnicowanie ludu Bożego, na trzy grupy, Boski Logos jest również jedynym nauczycielem ( $\delta \imath \delta \alpha ́ \sigma \kappa \alpha \lambda o \varsigma)$ oraz lekarzem (i $\alpha \tau \rho o ́ \varsigma)$ swego ludu, który leczy z chorób grzechowych ${ }^{17}$.

Współpracownikami Boskiego Logosu w Jego misji wychowawczej są aktualnie w Kościele - zdaniem Klemensa - alumni „trzeciej grupy” Szkoły Logosu - przyjaciele Chrystusa zwani też gnostykami. Mają oni udział zarów-

${ }^{9}$ Por. Joannes Chrysostomus, De inani gloria et de educandis liberis 52; 81-82, (dalej: De inani gloria), SCh 188, tłum. W. Kania, w: Św. Jan Chryzostom, O matżeństwie, wychowaniu dzieci i ascezie, BOK 19, Kraków 2002, 73-105; J. Dumortier, L'éducation des enfants Au IV siècle. La témoignage de S. Jean Chrysostome, „Revue des Sciences Humaines” 15 (1947) 222-238.

${ }^{10}$ Por. Joannes Chrysostomus, De inani gloria 81.

${ }^{11}$ Por. Clemens Alexandrinus, Paedagogus I 75, 1; 81, 1; 97, 3; 100, 2.

${ }^{12}$ Por. tamże I 96, 3, GCS 12, 147; zob. tamże I 57, 3; 58, 1.

${ }^{13}$ Por. Stromata I 20, 1; 28, 2.

${ }^{14}$ Tamże I 90, 1, GCS 52, 58, thum. J. Niemirska-Pliszczyńska: Klemens Aleksandryjski, Kobierce, I, Warszawa 1994, 65. Wszystkie teksty Stromata cytuję w tym przekładzie.

${ }^{15}$ Tamże VI 41, 6 - 42, 3, GCS 12, 123.

${ }^{16}$ Paedagogus I 55, 2, GCS 12, 123; por. Stromata VI 42, 1.

${ }^{17}$ Por. Paedagogus III 98, 1-3; III 99, 1-2; I 6, 1-4. 
no w funkcji „leczniczej”, jak i wychowawczej oraz nauczycielskiej Boskiego Pedagoga ${ }^{18}$. Prawdziwi gnostycy - przyjaciele Boga - są według Klemensa „mężami dojrzałymi w miłości do Boga"19, „mężami w pełni sprawiedliwymi” ${ }^{20}$, „którzy żyli w sposób doskonały według Ewangelii” ${ }^{21}$. Do prawdziwego gnostyka Klemens stosuje określenie „,wzniosły kapłan Boży”22. Gnostykowi zostało powierzone ,zadanie wychowawcze ku naprawie ludzi”23.

Udział w funkcji wychowawczej Boskiego Logosu przyznaje Klemens diakonom, prezbiterom i biskupom na tyle, na ile zrealizowali w swym życiu ideał prawdziwego gnostyka - przyjaciela Boga, jak twierdzi Klemens:

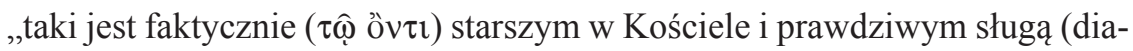
konem) woli Bożej, jeśli sam pełni i wykłada przykazania Boże. I nie dlatego uważany jest za sprawiedliwego, że przez ludzi został wybrany i także nie dlatego, że jest on starszy, lecz dlatego, że jest sprawiedliwy, zaliczany do rady starszych" 24 .

Według Klemensa udział w misji pedagogicznej Boskiego Logosu mają ci wszyscy, którzy osiągnęli status przyjaciół Boga. Mogą być nimi zarówno przedstawiciele hierarchii kościelnej, jak i ci wszyscy przedstawiciele laikatu, którzy przez doskonałą miłość w pełni upodobnili się do Boskiego Logosu ${ }^{25}$.

Jan Chryzostom rolę formacyjną w procesie wychowawczym przyznaje następującym osobom:

1. Rodzice - wychowanie dzieci jest podstawowym zadaniem i powinnością rodziców ${ }^{26}$, przy czym ojciec troszczy się głównie o wychowanie syna, matka o wychowanie córki ${ }^{27}$; niektóre działania wychowawcze wobec córki i syna powierza się obojgu rodzicom ${ }^{28}$.

2. Wychowawcy i opiekunowie - winni być starannie dobrani ${ }^{29}$ :

„Aby dziecko wychować potrzeba dzielnego wychowawcy”30.

\footnotetext{
${ }^{18}$ Por. Stromata VII 52, 1-3; 53, 1-6.

${ }^{19}$ Tamże VII 67, 2, GCS 17, 48, Niemirska-Pliszczyńska, II 271.

${ }^{20}$ Tamże VI 107, 2, GCS 52, 485, Niemirska-Pliszczyńska, II 176.

${ }^{21}$ Tamże VI 106, 1, GCS 52, 485, Niemirska-Pliszczyńska, II 175.

${ }^{22}$ Tamże VII 36, 2, GCS 17, 28, Niemirska-Pliszczyńska, II 246.

${ }^{23}$ Tamże VII 3, 4, GCS 17, 4, Niemirska-Pliszczyńska, II 219.

${ }^{24}$ Tamże VI 106, 2, GCS 52, 485, Niemirska-Pliszczyńska, II 175.

${ }^{25}$ Por. F. Drączkowski, Ideat kapłaństwa w pismach Klemensa Aleksandryjskiego, „Verbum Vitae" 12 (2007) 141-146.

${ }^{26}$ Por. Joannes Chrysostomus, De inani gloria 22.

${ }^{27}$ Por. tamże 90.

${ }^{28}$ Por. tamże 39, 40 i 90.

${ }^{29}$ Por. tamże 37, SCh 188, 128, BOK 19, 86.

${ }^{30}$ Tamże 16, SCh 188, 98, BOK 19, 79.
} 
3. Służba i domownicy:

„Tylko wypróbowani winni pomagać w kształtowaniu Bożego obrazu”31;

„Jeśli nikt z nich nie nadaje się, należy szukać za zapłatą człowieka szlachetnego i jemu należy powierzyć wychowanie" ${ }^{\text {32 }}$.

\section{Przełożony kościelny:}

„Niech młodzieniec odwiedza często przełożonego kościoła i słucha od niego pochwał dobrego życia"s3.

3. Metoda. Mając na uwadze zasadę akomodacji oraz różnorodność ludzkich usposobień Boski Pedagog - zdaniem Klemensa - stosuje odrębne metody w stosunku do każdego ludzkiego indywiduum:

„Logos dostosowuje się odpowiednio do charakteru każdego człowieka: raz postępuje gwałtownie innym razem z pobłażliwością" ${ }^{34}$.

Wobec trzech wyżej wymienionych grup alumnów swej Szkoły, stosuje odmienne metody wychowawcze:

a) Ludzi zatwardziałego serca - niewolników nałogów grzechowych, stosuje bądź kary i nagany, bądź zachęty i rady. Zagrożenie karą wyzwala obawę, która powstrzymuje od zła:

„Ci, którzy są trudni do wyleczenia, leczeni będą za pomocą groźby, zarzutu i nagany, tak jak żelazo jest obrabiane za pomocą ognia, młota i kowadła"35.

Mając na uwadze stopień surowości nagany, Klemens Aleksandryjski wylicza jej następujące rodzaje: napomnienie, narzekanie, krytyka, drwina, zarzut, zniewaga, ostre upomnienie oraz oskarżenie ${ }^{36}$.

Do środków pozytywnego oddziaływania należą obietnice, zachęty i rady:

„Są trzy sposoby doradzania: pierwszy bierze przykłady z przeszłości, jak np., jaką karę ponieśli Żydzi, kiedy oddawali cześć złotemu cielcowi; jaką karę ponieśli, gdy oddawali się nierządowi, i inne podobne przykłady. Drugi jest uważnym przyglądaniem się sprawom obecnym [...]. Na sprawach przyszłych opiera się trzeci sposób dawania rady, który zachęca, aby bacznie przyglądać się temu, co nadchodzi; toteż zostało powiedziane: ci, którzy po-

\footnotetext{
${ }^{31}$ Tamże 38 SCh 188, 130, BOK 19, 86.

${ }^{32}$ Tamże.

${ }^{33}$ Tamże 83 SCh 188, 190, BOK 19, 102.

${ }^{34}$ Clemens Alexandrinus, Paedagogus I 66, 5, GCS 12, 129.

${ }^{35}$ Tamże I 94, 1, GCS 12, 145.

${ }^{36}$ Por. tamże I 76, 1 - 80, 2.
} 
padają w grzechy, «zostaną wyrzuceni na zewnątrz w ciemności: tam będzie płacz i zgrzytanie zębów»” (Mt 8, 12) 37. „Jest jeszcze inny rodzaj pedagogii - obietnica szczęścia. Przez Dawida mówi Pan: «Błogosławiony mąż, który nie zgrzeszył...»" ${ }^{\prime 3}$.

b) Wierni słudzy. Na tym etapie środkiem motywującym dobre postępowanie jest idea posłuszeństwa oparta na autorytecie doskonałego Pedagoga, którego przykazania są „dobre, święte i sprawiedliwe” (Rz 7, 12) ${ }^{39}$. „Wierny sługa odczuwa obawę przed Bogiem, swym Panem”"40; „obawia się uchybić Ojcu"41, którego kocha. Bojaźń Boża motywuje wierność Bożym nakazom, zawartym w przykazaniach:

„Przykazanie wyraża zakaz, zawieszając ze względów wychowawczych obawę nad głowami tych, którzy z kolei dzięki niej zastosują się do napomnienia" ${ }^{\prime 2}$.

Boski Pedagog skłania „wiernego sługę” do posłuszeństwa przykazaniom, opartego na Bojaźni Bożej.

c) Przyjaciele Boga osiągają etap najwyższy na drodze doskonalenia, etap miłości doskonałej. Ta miłość, motywuje ich całe postępowanie:

„[Przyjaciel Boga] nie podlega pożądaniom, ani jakimś pragnieniom, ani nie odczuwa braku czegokolwiek innego w zakresie duszy (gdyż ma wszystko), trwając poprzez miłość w zjednoczeniu z tym, który jest przedmiotem jego ukochania" .

Poprzez miłość doskonałą osiąga heroiczność cnót. Przyjaciel Boga „znosi wszystko, wszystko wytrzymuje z miłości, nie dlatego, aby ludziom się podobać, lecz Bogu" ${ }^{4}$. Wszystko, tzn. nie tylko śmierć męczeńską, ale różnego rodzaju prześladowania i represje, jak: pozbawienie praw obywatelskich, wygnanie, konfiskatę mienia, rzucenie na pożarcie zwierzętom, próbę mąk ogniowych ${ }^{45}$.

Jan Chryzostom proponuje stosowanie zróżnicowanych środków wychowawczych, stosując gradację, od bardzo łagodnych do coraz surowszych:

\footnotetext{
${ }^{37}$ Tamże I 90, 2 - 91, 1, GCS 12, 143.

${ }^{38}$ Tamże I 92, 1, GCS 12, 144.

${ }^{39}$ Stromata III 84, 1, GCS 52, 234, Niemirska-Pliszczyńska, I, 278.

${ }^{40}$ Tamże I 173, 6, GCS 52, 107, Niemirska-Pliszczyńska, I, 119.

${ }^{41}$ Tamże II 53, 4, GCS 52, 142, Niemirska-Pliszczyńska, I, 166.

${ }^{42}$ Tamże II 32, 3, GCS 52, 130, Niemirska-Pliszczyńska, I, 151.

${ }^{43}$ Tamże VI 72, 1, GCS 52, 467, Niemirska-Pliszczyńska, II, 154.

${ }^{44}$ Tamże VII 70, 2-3, GCS 17, 52.

${ }^{45}$ Por. tamże IV 52, 3.
} 
a) Napomnienie:

„Gdy przekracza [dziecko] nakaz ukarz je, już to surowym spojrzeniem, już to energicznym upomnieniem, już to ostrą naganą"46.

b) Groźba kary:

„Niech się boi bicia, lecz niech nie będzie bity; można mu grozić pasem, ale nie należy nim bić" ${ }^{47}$.

c) Kara fizyczna - stosowana wyjątkowo:

„Nie karz często biciem i nie przyzwyczajaj się do tego sposobu wychowania. Dziecko ustawicznie bite uczy się gardzić biciem, a gdy to zajdzie za daleko, wszystko będzie daremne. Jeśli twa surowość sprowadza poprawę, zaprzestań jej nieco. Natura nasza potrzebuje też łagodności”"48.

d) Współzawodnictwo:

„Nic tak bowiem nie działa, jak współzawodnictwo. Ono podtrzymuje chłopca we wszystkim, zwłaszcza gdy jest on do współzawodnictwa skłonny. Współzawodnictwo ma większy wpływ od gróźb i zakazów, i innych środków”49.

e) Nagroda oraz rozrywka:

„Obmyślmy potem dla niego [dziecka] inne niewinne uciechy. Zaprowadźmy go do świętych mężów, przygotujmy rozrywkę, zróbmy mu radość przez różne podarunki" ${ }^{\circ 0}$; „dajmy mu nadzieję nagrody" ${ }^{\text {1 }}$.

f) Okazywać miłość. Słowom pouczenia winny towarzyszyć oznaki miłości:

„Przy tych słowach uściskaj go, by odczuł twą miłość”52.

g) Wychowywać przez dobry przykład ${ }^{53}$.

h) Jednolitość metody stosowanej przez wszystkich wychowawców:

„Zwróć uwagę i matce, aby dała chłopcu te same nauki, również wychowawcy i służące mu"s4.

\footnotetext{
${ }^{46}$ Joannes Chrysostomus, De inani gloria 30, SCh 188, 120, BOK 19, 84.

${ }^{47}$ Tamże.

${ }^{48}$ Tamże.

${ }^{49}$ Tamże 77, SCh 188, 178-180, BOK 19, 99.

${ }^{50}$ Tamże 78, SCh 188, 180, BOK 19, 99.

${ }^{51}$ Tamże 30, SCh 188, 120, BOK 19, 84; por. tamże 67.

52 Tamże 78, SCh 188, 182, BOK 19, 100.

${ }^{53}$ Por. tamże 37 i 70.

${ }^{54}$ Tamże 32, SCh 188, 124, BOK 19, 85; por. tamże 90.
} 
4. Program formacji pedagogicznej. Według Klemensa istnieją dwa zasadnicze źródła ludzkich błędów, które dają się sprowadzić do braków w zakresie formacji intelektualnej oraz braków w zakresie formacji moralnej: 
„Z tych dwu braków w wypadku pierwszego nie uzyskują ludzie właściwego sądu; w wypadku drugiego - nie są w stanie podążać za tym sądem, który prawidłowo wyprowadzili. [...] Zgodnie z tym są do dyspozycji dwie odmienne zasady wychowawcze ( $\delta$ ó $\pi \alpha 1 \delta \varepsilon \hat{\imath} \alpha \imath$ ) do każdego z dwu błędów [...]. Obydwie te formacje współrosną do doskonałej miłości ${ }^{55}$.

a) Formacja intelektualna (pierwsza paideia). W ujęciu Klemensa Aleksandryjskiego składa się z czterech etapów, opisanych w jego dziele Stromata:

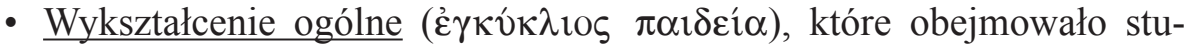
dium ośmiu przedmiotów: gramatyki, retoryki, geometrii, arytmetyki, astronomii, muzyki, harmonii oraz metryki ${ }^{56}$.

- Filozofia (filosofia). Klemens Aleksandryjski kładzie akcent na studium filozofii ,,zgodnej z Chrystusem”57. Jego zdaniem filozofia jest: „,właściwą postawą wobec mądrości podanej przez Syna"58, „gorliwym praktykowaniem mądrości”59; ,poszukiwaniem prawdy”60; „wiedzą o samym dobru i prawdzie"61. Filozofia pełni ważną funkcję w formacji intelektualnej oraz moralnej: ,jest współprzyczyną i czynnikiem współdziałającym w chwytaniu Prawdy"62; , prowadzi do udziału w mądrości dzięki umiejętności wrażliwego postrzegania"63; ,uzdalnia do teoretycznego kontemplowania bytów”64; „ułatwia zrozumienie wszelkich zawiłości myślowych"65; „pomaga temu, kto zapragnął uzyskać poznanie duchowe"66, ,prowadzi do sprawiedliwości”67; „ukierunkowuje na dobro"68; „czyni ludzi zacnymi i cnotliwymi”"69; „uczy powściągliwości”70; ,pro-

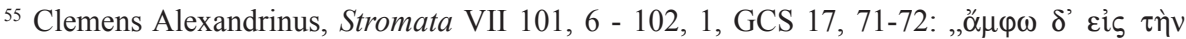

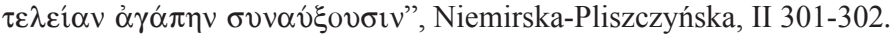

56 Por. F. Drączkowski, Struktury semantyczne wyrazu $\pi \alpha 1 \delta \varepsilon i ́ \alpha w$ dziele Klemensa Aleksandryjskiego $\Sigma \tau \rho \omega \mu \alpha \tau \varepsilon \hat{\imath}$, w: Z zagadnień literatury greckiej, red. J. Pliszczyńska, Lublin 1978, 127-151.

${ }^{57}$ Por. Clemens, Stromata VI 67, 1.

${ }^{58}$ Tamże VI 54, 1, GCS 52, 459, Niemirska-Pliszczyńska, II 143.

${ }^{59}$ Tamże I 30, 1, GCS 52, 19, Niemirska-Pliszczyńska, I 22.

${ }^{60}$ Tamże I 97, 1, GCS 52, 62, Niemirska-Pliszczyńska, I 71.

${ }^{61}$ Tamże I 93, 4, GCS 52, 60, Niemirska-Pliszczyńska, I 68.

${ }^{62}$ Tamże I 99, 1, GCS 52, 63, Niemirska-Pliszczyńska, I 72.

${ }^{63}$ Tamże VI 156, 1, GCS 52, 512, Niemirska-Pliszczyńska, II 207.

${ }^{64}$ Tamże VI 154, 4, GCS 52, 511, Niemirska-Pliszczyńska, II 206.

${ }^{65}$ Tamże I 20, 3, GCS 52, 14, Niemirska-Pliszczyńska, I 15.

${ }^{66}$ Tamże I 98, 2, GCS 52, 62, Niemirska-Pliszczyńska, I 71.

${ }^{67}$ Tamże I 99, 3, GCS 52, 63, Niemirska-Pliszczyńska, I 72.

${ }^{68}$ Tamże VI 159, 8, GCS 52, 514, Niemirska-Pliszczyńska, II 209.

${ }^{69}$ Tamże VI 159, 6, GCS 52, 513, Niemirska-Pliszczyńska, II 209.

${ }^{70}$ Tamże II 110, 1, GCS 52, 173, Niemirska-Pliszczyńska, I 202. 
wadzi do szczęścia przez cnotę"71. Ogólnie mówiąc „filozofia służy ulepszaniu duszy"72.

- Mądrość (sofia). Alumni Szkoły Logosu winni upodabniać się do Boga przez udział w jego Mądrości. Klemens Aleksandryjski w dziele Stromata określa istotę mądrości prawdziwej oraz jej funkcje. Podmiotem mądrości jest Bóg i ci, ,którzy zostali wyniesieni do bytu Boskiego"73. Przedmiotem mądrości jest „stałe i nienaruszalne poznanie oraz stałe i niezmienne zrozumienie spraw Boskich i ludzkich, obejmujące przeszłość, teraźniejszość i przyszłość"74. Źródłem mądrości jest to, co Syn objawił, czyli Stary i Nowy Testament oraz Słowo Boże żywe w Tradycji i nauce Kościoła ${ }^{75}$. Z tej racji Pismo Święte winno stać się przedmiotem nieustannych studiów, zgodnych z zasadami egzegezy Kościoła prawdziwego ${ }^{76}$. Mądrość prawdziwą należy odróżnić od pseudomądrości ${ }^{77}$.

- Poznanie misteryjne (mistyczne) - gnoza prawdziwa. Dotyczy poznania Boga i spraw Boskich, w stopniu najwyższym, dostępnym ludzkiej naturze; udziela go Boski Logos swym przyjaciołom:

„istotnie doskonała wiedza wznosi się ponad świat doczesny, zajmując się sprawami myślowymi oraz bardziej jeszcze duchowymi, których oko nie ujrzało, ani ucho nie słyszało i które nie dotarły do serca ludzi, dopóki nie udzielił nam wiedzy o nich sam Nauczyciel, odsłaniając co święte nad świętymi i co świętsze od niego na wyższym jeszcze stopniu - ale tylko tym, którzy są dziedzicami synostwa Pańskiego w sposób prawdziwy, a nie domniemany"78.

To poznanie osiągane jest na etapie miłości doskonałej, określanej jako „miłość gnostyczna" "79. Gnoza prawdziwa ,jest rodzajem doskonalenia się (teleíosis), które obejmuje zarówno sferę intelektualną jak i moralną"80. Doskonała miłość (agápe) „rodzi się pod wpływem gnozy”81 i przez nią się doskonali.

b) Formacja moralna (druga paideia). W ujęciu Klemensa Aleksandryjskiego, składa się również z czterech etapów, opisanych w Stromateis:

\footnotetext{
${ }^{71}$ Tamże I 98, 2, GCS 52, 62, Niemirska-Pliszczyńska, I 71.

${ }^{72}$ Tamże VII 3, 2, GCS 17, 4, Niemirska-Pliszczyńska, II 218.

${ }^{73}$ Tamże VI 125, 4, GCS 52, 495, Niemirska-Pliszczyńska, II 188.

${ }^{74}$ Tamże VI 61, 1, GCS 52, 462, Niemirska-Pliszczyńska, II 147.

${ }^{75}$ Por. tamże VI 54, 1; VII 92, 3.

${ }^{76}$ Por. tamże VII 92, 3, GCS 17, 65, Niemirska-Pliszczyńska, II 293.

${ }^{77}$ Por. tamże VII 98, 1, GCS 17, 69, Niemirska-Pliszczyńska, II 298.

${ }^{78}$ Tamże VI 68, 1, GCS 52, 465, Niemirska-Pliszczyńska, II 151; por. 1Kor 2, 9.

${ }^{79}$ Por. tamże IV 130, 5, GCS 52, 305, Niemirska-Pliszczyńska, I 369.

${ }^{80}$ Tamże VII 55, 1, GCS 17, 40, Niemirska-Pliszczyńska, II 261.

${ }^{81}$ Tamże VII 59, 4, GCS 17, 43, Niemirska-Pliszczyńska, II 265.
} 
- Posłuszeństwo przykazaniom oparte na bojaźni Bożeje2;

- Powściągliwość oparta na nadziei ${ }^{83}$;

- Ćwiczenie się w dobrym oparte na naśladowaniu dobroci Boga ${ }^{84}$;

- Pełne zespolenie woli człowieka z wolą Bożą - Mądrość gnostyczna ${ }^{85}$.

Jan Chryzostom w rozprawie $O$ wychowaniu dzieci (De inani gloria) kreśli program wychowania dzieci, dając priorytet formacji moralno-religijnej. Jego

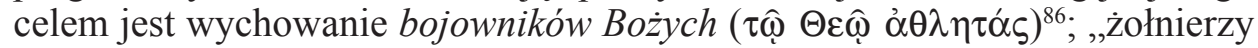

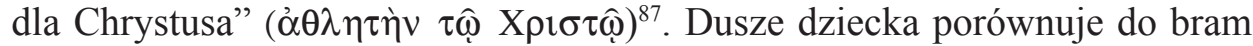
miasta: „miastem jest dusza dziecka”88; „Bramami miasta są oczy, język, słuch, węch i dotyk. Przez te bramy wchodzi zguba i błogosławieństwo w życie duszy" "99. Mając na uwadze wyżej wymienione władze duszy, wylicza kolejno wartości, które należy pielęgnować i wady, które należy zwalczać w procesie formacji:

- Język - „Nauczmy dzieci wypowiadać tylko przystojne i pobożne słowa" ${ }^{90}$, „Niech otwiera dziecko usta dla dziękczynienia i świętych hymnów, niech mówi zawsze o Bogu i filozofii wzniosłego życia"91; niech odrzuci „obraźliwe słowa, obelżywe mowy i nieprzystojne żarty"92; niech dziecko „nie wypowie nic nieprzyzwoitego, obraźliwego, nierozumnego, lecz słowa godne Pana" ${ }^{\prime 3}$.

- Słuch - „Nie powinny dzieci słyszeć złych mitów i bajek”94. Należy dziecku opowiadać historie biblijne: o Kainie i Abluํ, o Jakubie

\footnotetext{
${ }^{82}$ Por. tamże II 55, 5; IV 108, 4.

${ }^{83}$ Por. tamże III 4, $1 ; 57,1$; II 41, 1.

${ }^{84}$ Por. tamże II 41, 3; 87, 2; III 54, 4; 56, 2.

${ }^{85}$ Por. tamże IV 55, 3; 66, 2-3; 14, 3; 43, 2; 130, 5 .

${ }^{86}$ Joannes Chrysostomus, De inani gloria 90, SCh 188, 196, BOK 19, 103; por. M. Falanga, Il pensiero pedagogico di Giovanni Crisostomo, Bari 1981, 61-92 (La concezione pedagogica); S. Abengochea, Ideas pedagogicas de S. Juan Crisóstomo, „Helmantica” 12 (1961) 343-360; T. Kołosowski, Wychowanie religijno-moralne dzieci w rodzinie $w$ świetle traktatu „O wychowaniu dzieci” św. Jana Chryzostoma, „Seminare” 17 (2001) 405-420.

${ }^{87}$ Joannes Chrysostomus, De inani gloria 19, SCh 188, 102, BOK 19, 80.

${ }^{88}$ Tamże 25, SCh 188, 112, BOK 19, 82.

${ }^{89}$ Tamże 27, SCh 188, 114, BOK 19, 83.

${ }^{90}$ Tamże 28, SCh 188, 114, BOK 19, 83.

${ }^{91}$ Tamże, SCh 188, 114, BOK 19, 83-84.

${ }^{92}$ Tamże 28, SCh 188, 114, BOK 19, 83 .

${ }^{93}$ Tamże 34, SCh 188, 124, BOK 19, 85.

${ }^{94}$ Tamże 38, SCh 188, 128, BOK 19, 86 .

${ }^{95}$ Por tamże 39.
} 
i Ezawie ${ }^{96}$, o synu marnotrawnym ${ }^{97}$. „Niech chłopiec uczy się pobożnych pieśni”"98; „Niech więc nie słyszą dzieci niczego niestosownego ani od służących, ani od wychowawcy, ani od opiekunów" "99. „Gdy dziecko podrośnie opowiedz mu jeszcze inne historie (biblijne). Napełnią je one zbawienną bojaźnią" "100; „Gdy jednak ma już lat piętnaście czy więcej, niech usłyszą o piekle..."

- Powonienie - „Niech nikt nie stosuje wonnych maści, bo zaraz umysł odczuwa miłą woń i czyni ciało ospałym"102.

- Oczy - „Wskaż mu piękne przedmioty, aby jego oczy odwróciły się od złych rzeczy, wskaż na niebo i gwiazdy, na ziemię i jej kwiaty, na łąki i obrazki w kwiatach, niech tymi rzeczami zachwycają się oczy. Tyle jest piękna, które nie przynosi żadnej szkody"103.

- Dotyk - „Nie dopuść do wydelikacenia ciała przez szaty ani do poufnego zetknięcia się z ciałem innego człowieka. Hartujmy ciało, by wycho-

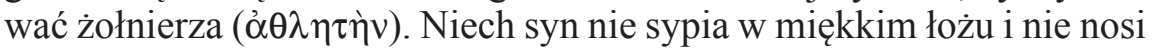
miękkiej szaty. W ten sposób trzymajmy zmysł dotyku w ryzach"104.

5. Cel wychowania. Według Klemensa Aleksandryjskiego celem wychowania jest człowiek doskonale miłujący Boga i bliźniego, święty. Życie takiego człowieka jest antycypacją nieba na ziemi ${ }^{105}$. Ideał ten realizuje się w życiu przyjaciela Boga - gnostyka. Doskonały chrześcijanin - gnostyk, który osiąga doskonałą miłość - „miłość gnostyczną”, ,zawsze kocha Boga i tylko na Niego jest całkowicie ukierunkowany" ${ }^{106}$. Miłość Boga całkowicie go wypełnia i absorbuje, zastępując mu wszystko. Dlatego przyjaciel Boga:

${ }^{96}$ Por. tamże 43; zob. W. Kania, Pierwsza katecheza domowa w ujęciu św. Jana Chryzostoma, VoxP 5 (1985) z. 8-9, 215-222.

${ }^{97}$ Por. tamże 46.

${ }^{98}$ Tamże 60, SCh 188, 158, BOK 19, 94; por. S. Longosz, Śpiew w rodzinie środkiem wychowania w pedagogii św. Jana Chryzostoma, „Roczniki Nauk o Rodzinie” 1 (2009) 13-55.

${ }^{99}$ Tamże 37, SCh 188, 128, BOK 19, 86.

${ }^{100}$ Tamże 52, SCh 188, 150, BOK 19, 92.

${ }^{101}$ Tamże.

${ }^{102}$ Tamże 54, SCh 188, 152, BOK 19, 93

${ }^{103}$ Tamże 59, SCh 188, 156, BOK 19, 94.

${ }^{104}$ Tamże 63, SCh 188, 162, BOK 19, 95.

${ }^{105}$ Por. Clemens Alexandrinus, Stromata VII 102, 1; VI 73, 4.

106 Tamże VI 71, 4, GCS 52, 467, Niemirska-Pliszczyńska, II 153; por. IV 29, 3; 130, 5; VII 46, 3 . 
„nie podlega pożądaniom, ani jakimś pragnieniom, ani nie odczuwa braku czegokolwiek innego w zakresie duszy (gdyż ma wszystko), trwając poprzez miłość w zjednoczeniu z tym, który jest przedmiotem jego ukochania"107.

„Gnostyk coraz ściślej jednoczy się z Bogiem stając się zarazem wzniosły i wesoły we wszystkim; wzniosły - poprzez stałe odnoszenie się do tego, co boskie, wesoły zaś - poprzez uświadamianie sobie wielkości dóbr ludzkich, jakie nam darował Bóg"108.

Przyjaciel Boga jest nieustannie zjednoczony z Bogiem poprzez modlitwę i kontemplację ${ }^{109}$. „Całe jego życie jest jedną świętą uroczystością"110. Gnostyk już tutaj na ziemi równy jest aniołom ${ }^{111}$. „,Gnostykowi pomaga sam Bóg i wyraża mu swe poważanie przez bardziej bezpośrednią opiekę"112. Przyjaciel Boga przez całe życie studiuje Pismo Święte i stara się zgłębić naukę Kościoła ${ }^{113}$. Gnostyk upodabniając się do Boga osiąga udział w Jego mądrości oraz świętości, wyróżniając się łagodnością, miłością do człowieka oraz wzniosłą pobożnością ${ }^{114}$ :

„Jest więc dusza gnostyka w każdej sytuacji pełna siły jak ciało atlety (ô̂ov $\alpha \dot{\alpha} \theta \lambda \eta \tau o \hat{v} \tau$ ò $\sigma \hat{\omega} \mu \alpha)$ utrzymane w największej kondycji i mocy"115.

Należy podkreślić, że ideał życia kontemplacyjnego przyjaciel Boga łączy z aktywnością rodzinną, ekonomiczną i społeczną. Gnostyk - zdaniem Klemensa:

„prawdziwym mężczyzną okazuje się nie przez wybór dla siebie życia samotnego, lecz tym zwycięża mężów, iż troszcząc się o małżeństwo, płodzenie dzieci oraz opiekę nad domem, jednocześnie nie wykazuje wrażliwości ani na rozkosz, ani na ból. Mimo kłopotów o dom, nie daje się oderwać od miłości do Boga, zwycięsko wychodząc z wszelkiej próby, na jaką tylko wystawia go sytuacja ojca rodziny, męża, pana służby i właściciela majątku"116.

W życiu przyjaciela Boga realizuje się ideał życia kontemplacyjnego oraz praktycznego. Ideał ten znajdzie później szerokie rozwinięcie w nauce Grzegorza Wielkiego ${ }^{117}$.

\footnotetext{
${ }^{107}$ Tamże VI 72, 1, GCS 52, 468, Niemirska-Pliszczyńska, II 154.

${ }^{108}$ Tamże VII 35, 7, GCS 17, 28, Niemirska-Pliszczyńska, II 246.

${ }^{109}$ Por. tamże VII 44, 7.

${ }^{110}$ Tamże VII 49, 4, GCS 17, 37, Niemirska-Pliszczyńska, II 256.

${ }^{111}$ Por. tamże VI 105, 1, GCS 52, 484-485, Niemirska-Pliszczyńska, II 175.

${ }^{112}$ Tamże VII 48, 1, GCS 17, 36, Niemirska-Pliszczyńska, II 255.

${ }^{113}$ Por. tamże VII 104, 1-2.

${ }^{114}$ Por. tamże VI 125, 4; VII 13, 2 - 14, 1.

115 Tamże VII 64, 4-5, GCS 17, 46-47, Niemirska-Pliszczyńska, II 268.

116 Tamże VII 70, 7, GCS 17, 51, Niemirska-Pliszczyńska, II 274; por. tamże VI 64, 1-2.

117 Por. R. Buliński, Program pracy duszpasterskiej papieża Grzegorza Wielkiego w świetle
} 
Celem wychowania, jaki stawia Jan Chryzostom, jest wychowanie

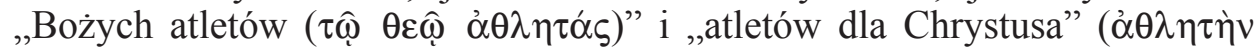
$\tau \hat{\omega} \mathrm{X} \rho \tau \tau(\hat{\omega})^{118}$. W dziele De inani gloria zwraca uwagę zarówno na formację moralną, jak też intelektualną. W procesie formacji integralnej „Bożego atlety" przyjmuje zasadę złotego środka, zwracając uwagę na kształtowanie cnót dopełniających się: męstwa, odwagi, opanowania, trzeźwości, czujności i hartu ducha i ciała oraz łagodności, uprzejmości i skromności. Należy wypowiedzieć walkę takim wadom jak: gniewowi, nieopanowaniu, pijaństwu i zbytkowi (luksusowi). Wiele uwagi poświęca Jan kształtowaniu wstrzemięźliwości seksualnej ${ }^{119}$, w tym szczególnie przedmałżeńskiej ${ }^{120}$. Ukoronowaniem całej formacji jest mądrość: ,aby chłopca wychować ku mądrości i wykluczyć z jego życia wszelką głupotę"121. Mądrość to przede wszystkim ,wiedza o Bogu, o dobrach, które są dla nas po tamtej stronie, o piekle, o królestwie niebieskim, bo «początkiem mądrości jest Bojaźń Boża» (Syr 1,7)"122. Należy wyrobić w wychowankach dystans wobec dóbr tego świata: „Nic tak bowiem nie ogłupia jak przywiązanie do bogactwa, potęgi i sławy" ${ }^{123}$. Należy jednak dzieci przygotować do udziału w życiu publicznym. Taki proces formacji prowadzi do realizacji ideału ,atlety Bożego"124.

W koncepcji wychowania obu wyżej omówionych autorów występują specyficzne różnice i podobieństwa. Różnice najbardziej są dostrzegalne w kwestii określenia, jakie osoby należy zaliczyć do grupy wychowanków oraz jakie osoby należy zaliczyć do grona wychowawców. W koncepcji Klemensa Aleksandryjskiego wychowankami „Boskiej pedagogii” są wszyscy ludzie wierzący, przynależni do różnych grup wiekowych, to jest zarówno dzieci, jak i młodzież oraz dorośli i starsi wiekiem. Innymi słowy, wychowankami są wszyscy przynależni do ludu Bożego. Jan Chryzostom do grupy wychowanków zalicza tylko dzieci i młodzież do czasu zawarcia małżeństwa. Łatwo

\footnotetext{
eksportacji pastoralnych zawartych w „XL Homiliarum in Evangelia”, Pelplin 2008. Uwagę zwraca rozdział IV: „Wychowanie ku kontemplacji Boga oraz radości nieba”.

118 Por. Joannes Chrysostomus, De inani gloria 90, 19, zob. wyżej n. 86 i 87. Termin $\dot{\theta} \lambda \eta \tau$ ஸ́s przyjmuje znaczenia: ,szermierz, zapaśnik, atleta”, zob. Słownik grecko-polski, red. Z. Abramowiczówna, Warszawa 1958, t. I, s. 43. W. Kania w swym przekładzie termin ten oddał jako „,bojownik”, ,żołnierz”. W przekładzie SCh 188 (s. 196 i 102) jest: ,à Dieu en élevant de tels athlètes” (90); „Ĕlève un athlète pour le Christ” (19).

${ }^{119}$ Por. Joannes Chrysostomus, De inani gloria 76-79.

${ }^{120}$ Por. tamże 81-84.

${ }^{121}$ Tamże 85, SCh 188, 192, BOK 19, 102.

122 Tamże.

${ }^{123}$ Tamże 87, SCh 188, 192, BOK 19, 103.

${ }^{124}$ Por. tamże 90.
} 
zauważyć, że mimo tej różnicy wiekowej istnieje też podobieństwo: obaj autorzy zaliczają do grupy wychowanków tak dzieci jak i młodzież.

Podobnie ma się rzecz, jeśli chodzi o określenie osób przynależnych do grona wychowawców. Według Klemensa wychowawcą jedynym i najdoskonalszym jest Boski Logos, Jezus Chrystus. Współwychowawcami w misji pedagogicznej Syna Bożego są ci wszyscy, którzy upodobnili się do Niego, przyjaciele Boga, rekrutujący się zarówno z grupy hierarchów kościelnych (diakoni, prezbiterzy, biskupi), jak i z grona przedstawicieli laikatu. Jan Chryzostom mówiąc o wychowawcach, ma na uwadze określoną grupę osób, którymi są: rodzice, domownicy i służba oraz specjalnie dobrani wychowawcy. Należy zauważyć, że obaj omawiani Ojcowie Kościoła, kładą nacisk na doskonałość wychowawców - formatorów. Zarówno Klemens, jak i Jan Chryzostom żądają od wychowawców doskonałej formacji chrześcijańskiej. Klemens zaliczając do grona wychowawców ,przyjaciół Boga”, posługuje się określeniem ogólnym; Jan Chryzostom wylicza szczegółowo grupy osób pełniących zadania wychowawcze.

Najwięcej zbieżności znajdujemy w kwestii stosowania metod i środków wychowawczych. Obaj autorzy zaliczają do środków wychowawczych stosowanie upomnienia, nagany, groźbę kary i karę. Klemens widzi potrzebę stosowania kary wobec „zatwardziałych grzeszników” - Jan Chryzostom, wobec dzieci szczególnie opornych, ale tylko jako środka wyjątkowego. Obaj Ojcowie Kościoła mówią o potrzebie stosowania zachęty, nagrody oraz dobrego przykładu. Podobnie postrzegają potrzebę miłości, życzliwości i perswazji jako środków najważniejszych i podstawowych w procesie formacji wychowawczej.

Szereg zbieżności notujemy w programie wychowania obu autorów, którzy kładą nacisk na formację integralną, obejmującą kształcenie intelektu, woli oraz dobrych obyczajów. Liczne podobieństwa znajdujemy w programie formacji aretologicznej. Obaj autorzy akcentują potrzebę bojaźni Bożej, opanowania, cierpliwości i miłości wobec wszystkich ludzi. Różnice występują w zakresie formacji intelektualnej, co jest rzeczą zrozumiałą ze względu na to, że inne wymagania stawia się dzieciom i młodzieży, a inne osobom dojrzałym i starszym.

Powyższe podobieństwa dotyczą też celu wychowania, którym dla obu Ojców Kościoła jest doskonałość chrześcijańska, stosowna i odpowiednia dla miary wiekowej. Rzecz charakterystyczna, że obaj omawiani autorzy posługują się nawet tym samym terminem ,atleta”. Dla Klemensa przyjaciel Boga - gnostyk, jest „atletą ducha”. Jan Chryzostom twierdzi, że należy dążyć do wypracowania ideału ,atlety Chrystusa”, ,atlety Bożego”. Klemens traktuje o ideale człowieka dojrzałego duchowo i fizycznie - człowieka dorosłego; Jan Chryzostom ma na uwadze etap dojrzewania do pełni świętości.

W podsumowaniu należy stwierdzić, że obie koncepcje wychowania chrześcijańskiego - Klemensa Aleksandryjskiego i Jana Chryzostoma - w istotnych 
punktach są zbieżne i podobne. Pomimo ewidentnych różnic, zdradzają więcej podobieństw. Klemens prezentuje wizję wychowania uniwersalną, związaną z Kościołem, który jest szkołą Boskiego Logosu. Jan Chryzostom jest bardziej realistą i praktykiem. Jego zdaniem proces wychowania realizuje się $\mathrm{w}$ ramach „Kościoła domowego”. Klemens jest wybitnym teoretykiem - Jan Chryzostom duszpasterzem. Chociaż obie koncepcje różnią się, szczególnie w rozumieniu grupy wychowanków i wychowawców, w istocie rzeczy nie są przeciwstawne, lecz dopełniające. Obie koncepcje, odmienne w swych ujęciach, w istocie rzeczy są komplementarne, ponieważ wyrastają ze wspólnego pnia doktrynalnego, który stanowi nauka chrześcijańska oraz tradycja klasyczna.

\section{THE CONCEPTION OF THE CHRISTIAN EDUCATION IN CLEMENT OF ALEXANDRIA AND JOHN CHRYSOSTOM'S GRASP}

\section{(Summary)}

Presented paper consists of five main parts and focuses on the most important elements of their teaching about education and upbringing. The first part tells about pupils, next one about educator, the third about methods in the pedagogical process, the forth about programme of educative activity, and the last one about goal of that process. Although Clement and John Chrysostom present different point of view $\mathrm{f}$. e. on the understanding of the educator and pupils, their thought can be treated as complementary educational system because they follow from the same Christian doctrinal point and the classical tradition. 